Journal of Applied Finance \& Banking, Vol. 11, No. 2, 2021, 149-167

ISSN: 1792-6580 (print version), 1792-6599(online)

https://doi.org/10.47260/jafb/1126

Scientific Press International Limited

\title{
A Study of Project Financing on the Defense Industry in Systems Thinking Perspective
}

\author{
Day-Yang Liu', Chia-Kan Wang' ${ }^{2}$ Chung-Yi Fang ${ }^{3}$, and Pei-Leen Liu ${ }^{4}$
}

\begin{abstract}
Taiwan has long faced the threat of force from mainland China. Since Taiwan has limited defense industry autonomy, it has insufficient self-produced weapons and must rely on foreign weapon procurement for defense preparation. As a result, Taiwan ranks among the top 10 U.S. arms sales and exports destination due to the large quantity of armaments purchased. An autonomous defense industry capability covers three aspects: independent $\mathrm{R} \& \mathrm{D}$, production, and formation of the weapon industry chain. Due to the high complexity, strong integration, large capital investment, high technology threshold, and long payback period characteristics of the defense industry; promoting exchanges between the defense industry and private enterprises can effectively bolster economic development and enhance the country's industrial competitiveness in addition to upgrading its advanced technologies. In addition to the overall government planning and policy promotion, the defense industry also requires private sector participation. However, private manufacturers generally have insufficient financial resources and often need to obtain the necessary funds via project financing. So project financing plays a critical role to the defense industry development. There are numerous consideration factors for project financing and the defense industry. Such factors influence each other, and are correlated and interlinked. All aspects must be considered from a holistic and structural system perspective. But there is a dearth of literature focusing on the research of the defense industry and project financing from a systematic perspective. Therefore, the researcher of this study employed the system dynamics methodology and used system thinking to construct a qualitative system dynamic analysis model for Taiwan's defense industry and project financing system. The goal is to provide reference for countries that desire to develop their own national defense industry.
\end{abstract}

Keywords: Defense industry, Project financing, System dynamics, System thinking.

\footnotetext{
${ }^{1}$ Graduate Institute of Finance, National Taiwan University of Science and Technology, Taiwan.

${ }^{2}$ Graduate Institute of Finance, National Taiwan University of Science and Technology, Taiwan.

3 Department of Financial Management, National Defense University, Taiwan.

${ }^{4}$ Graduate School of Resources Management and Decision Science, Management College of National Defense University, Taiwan.
}

Article Info: Received: December 24, 2020. Revised: January 18, 2021.

Published online: January 27, 2021. 


\section{Introduction}

Taiwan has long faced the threat of force from mainland China. However, Taiwan's national defense independence often faces bottlenecks, and it lacks the system and driving force to independently develop and manufacture its own weapons. The technology of the industry has not been able to connect with the world, so Taiwan has relied on foreign weapons procurement for a long time. In addition to being a national security issue, national defense is also a critical strategic industry for the country. National defense armaments acquisition may be divided into three major categories: Foreign Military Sales (FMS), Direct Commercial Sales (DCS), and self-production of major defense equipment (MDE). Among these, MDE requires independent $\mathrm{R} \& \mathrm{D}$, production, and formation of the weapons industry chain. Defense industries for nations worldwide are mostly led and integrated by their governments. Advanced countries, such as the United States and Japan, have comprehensive defense industry plans, which are mostly operated by the private sector under the active guidance and strict control of the government to establish the overall national defense armaments plan and improve national defense security. The defense industry can also drive the technological development as well as industrial upgrade and promote the overall economic progress (Navarro, 2019). Taiwan's military procurement budget often reaches tens of billions of U.S. Dollars, and Taiwan ranks among the top 10 armament export targets for the United States. If part of the budget can be invested into the local defense-related industries to produce Indigenous Defense Submarines (IDS) and Indigenous Advanced jet trainers (IAJT), its defense industry can further drive the industry upgrade and development. Indeed, Taiwan's defense industry chain can supply half of the components required to manufacture its own jets (ships). Its national defense autonomy will bring approximately US $\$ 2.3$ billion in industrial revenue annually, accounting for $23 \%$ of the national defense budget. With the advancement of the defense industry plan, Taiwan's aerospace, shipbuilding, and information security related business opportunities are estimated to reach NT $\$ 250$ billion and add 8,000 job opportunities. Since 2001, the Taiwanese government has formulated laws to procure part of its armaments domestically in hopes to unleash the military equipment business opportunities, encourage private manufacturers to participate in the development of national defense armament, and establish its armament production and maintenance autonomy. The goal is to nurture Taiwan's own national defense industry, enhance its autonomous defense forces, transform the national defense projects into a source of industrial demand, and drive technological development and industrial upgrading.

The defense industry has the characteristics of high complexity, high technical threshold, large capital investment, and long payback period. A lot of resources and manpower must be invested in the process of autonomous defense industry development. If Taiwan can incorporate private sector participation, it can maximize the industrial upgrade benefits, improve the technical capabilities, and exert its national defense autonomy (Beck and Demirguc-Kunt, 2006). Although 
the Taiwanese government has continued to promote development for the major defense industries, the lack of an overall planning in the past has led to insufficient private investment willingness. The military technology development by private enterprises could not mature, and the private sector technologies could not be utilized for the military. After long-term development, the private and national defense systems cannot grow together or achieve synergy. In addition, Taiwanese manufacturers generally have insufficient financial resources. It is often necessary to obtain funds via project financing in order to meet the national defense needs and enhance industry competitiveness. Therefore, to encourage the manufacturers to invest in the defense industry, the Taiwanese government must assist manufacturers in obtaining project financing without increasing the government's financial burden so that private funds can be injected into the defense industry and help the nation to gradually achieve defense autonomy.

In summary, there are numerous consideration factors for the defense industry and project financing. Such factors influence each other, are correlated and interlinked, and the interaction between such factors is dynamic and complex. All aspects must be considered from a holistic and structural system perspective in order to better understand the entire picture. A review of existing literature indicated that the defense industry related studies mostly explored development policies (Navarro, 2019), and the project financing related studies mostly focused on large private projects (Keeley and Matsumoto, 2018; Cruz and Sarmento, 2018; Sainati, Locatelli, and Smith, 2019; Yates and Leybourne, 2019). There is a dearth of literature focusing on the defense industry and project financing from a systematic point of view. Therefore, the researcher of this study employed the system dynamics methodology and used system thinking to construct a qualitative and systematic dynamic analysis model for Taiwan's defense industry and project financing system. The goal is to provide reference for countries that desire to develop their own national defense industry.

As for the framework of this paper, Section 2 introduces the system thinking of system dynamics, Section 3 explores the defense industry and project financing related literatures, Section 4 uses system thinking to construct a qualitative analysis model and explores the causal interaction between the defense industry and project financing factors, and Section 5 presents the conclusion and recommendations.

\section{Literature Discussion}

\subsection{Project Financing}

Project financing is a method used to raise investment project funds. The financing method constructed via the Special Purpose Vehicle (SPV) refers to obtaining financing via SPV that specializes in new investment project operations; uses rights, natural resources, or other assets as collateral; and repays the loans from the project's income (Sainati et al., 2019). The future income of the project is regarded as the main source of funds to repay the loan. Banks provide financing and bear part of the risks for the success or failure of the project. Project financing is composed 
of investment case related contracts, and the content of the contracts is mostly intricate and complex. So the costs required are often substantial (John, 1996; Finnerty, 2013).

Enterprises must continue to undertake different investment projects in order to maintain their competitiveness and seek profit opportunities. However, due to the changes of times and continuous technological innovation, the complexity and scale of investment projects have gradually expanded. Because traditional corporate financing restricts financial flexibility, enterprises often cannot meet their capital needs via traditional financing due to financial risk considerations. Therefore, the project financing model that uses the future cash flow of the project as the source of repayment has gradually attracted attention (Keeley and Matsumoto, 2018; Yates and Leybourne, 2019). Compared to traditional financing that attaches great importance to the borrower's financial resources and the collateral provided, the borrower's limited financial resources and the guarantees are part of considerations at the start of a project financing implementation plan. Therefore, project financing uses future proceeds of the project plan as the main source of repayment, and the banks pay more attention to the feasibility assessment of the project plan (John and John, 1991; Broome, 2002; Merna and Njiru, 2002).

As the investment project is ongoing, investors must consider the project risks that can be controlled and the market risks that cannot be controlled (Kakimoto et al., 2000; Mohamed and McCowan, 2001). Governments and investors may face commercial risks, economic risks, moral hazard risks, and political risks (Yeo and Tiong, 2000; Spedding, 2009; Gatti, 2018). Traditional corporate financing is mostly short- or medium-term. There is usually historical information available for banks to assess the credit and solvency of borrowers. Banks also have full recourse against default borrowers, and their risk exposure is limited. However, project financing usually has the characteristics of long duration and high complexity, and is usually long-term. It would be difficult to judge the repayment ability of the project enterprise, and there is only limited recourse. Therefore, banks must bear higher risks compared to those of traditional loans, which affects the banks' willingness to finance projects. Banks would usually demand the project contract and the borrower's physical assets as collateral in order to reduce the project financing risks while charging higher interest fees (Katharine, 2004; Gatti, 2013). Many governments worldwide regard small and medium-sized enterprises (SMEs) as crucial for industrial policy development (Beal, 2001). However, because SMEs have fewer resources and lower opportunities to obtain capital financing and external technology, they must be assisted and guaranteed by the government (Bougrain and Haudeville, 2002). The government must work closely with investors to fully optimize the risk-sharing effect (Shen and $\mathrm{Wu}, 2005$ ). Therefore, to encourage domestic manufacturers to invest in the defense industry, the government must assist SMEs to obtain project financing without increasing the government's financial burden, inject private funds into the defense industry in order to enhance industrial competitiveness, and gradually help the nation to achieve security defense autonomy. (Kaivanto and Stoneman, 2007). 


\subsection{Defense Industry}

Countries have defense weapon needs due to external threats. National resources are transformed into usable armaments needed to complete military missions through R\&D or external procurement (Head, 1974). After deciding on the armaments that can meet the military mission needs, the government must also consider how to obtain the armaments. The source of acquisition is divided into two methods: "foreign procurement" and "domestic R\&D." To quickly establish combat readiness and alliances with weapon exporting countries, many nations often directly purchase international ready-made armaments (Jan, 2005). However, because the weapon market is a relatively closed system, it is difficult to internationalize and divide labor, and there are few sources of supply as well as low substitutability (James, 1978). Moreover, the defense industry is critical to national security. It is directly affected by national security policies, but indirectly affected by the socioeconomic policies and information technology (Wang, Nguyen, Le, and Hsueh, 2018). Therefore, obtaining armaments through autonomous R\&D and production by the defense industry is also regarded as crucial.

The defense industry is dominated by the domestic demand market, and then expanded to the international market. This market has high profitability, exclusivity, and monopoly. It also has the long payback period and high investment cost characteristics, and requires a large amount of capital investment to achieve sustainable development (Yeo and Tiong, 2000). Advanced countries, such as the United States and Japan, have comprehensive defense industry plans. Their defense industries can build and maintain the national defense armaments to ensure national defense security while driving the nation's technological development and industrial upgrade (Benoit, 1978; Landau, 1992). Due to domestic and international market demands, the defense industry of the world's major weapon exporting countries has reached an economic scale. Therefore, private enterprises have a high willingness to participate. Defense technology can be transferred to take root in the private sector (Amara, 2008). The defense industry technology $R \& D$ process represents huge investment in high-tech talents. Without long-term and stable policy support, it is impossible to get a return from such investment (Jan and Jan, 2000). To encourage private investment and accelerate social and economic development, many countries provide policy support to attract private funding. This model is more efficient than construction by the government through its own budgeting plans (Cruz and Sarmento, 2018; Esty, 2004). The government can continue to support the defense industry policies and improve its military capabilities while the supply chain of defense-related industries drives economic growth and international competitiveness (Blom, Castellacci, and Fevolden, 2013).

\section{System Dynamics Methodology and System Thinking}

System Dynamics is a management science methodology developed by Professor Jay W. Forrester of the Massachusetts Institute of Technology (MIT) in 1956. It is a teleological-based research method. During the early development phase, this 
method is applied to manufacturing, production, distribution, and long-term development analyses for cities, countries, and the world as well as economic growth research (Meadows et al., 1972; Meadows et al., 2004). System dynamics can provide a holistic view of system thinking, qualitatively describe complex problems, and interpret the causal structure of variables by analyzing the internal system intelligence feedback process for time lag and complex dynamics related issues (Hsiao, 2014). Using the causal feedback loop and visually recorded model structure to describe the system characteristics and dynamic development can help us to grasp the overall structural characteristics of the system. The components, symbols, and definitions of the system dynamics structure are shown in Table 1. In recent years, system dynamics application has been expanded from the field of engineering to organizational strategy, industrial economy, energy policy, and other social science fields (Sterman, 1988; Senge, 1990; Sterman, 2000; Jan and Hsiao, 2004; Chen and Jan , 2005a, 2005b; Hsiao et al., 2011; Hsiao and Liu, 2012; Trappey et al., 2012). Some scholars also use the system dynamics methodology to conduct national defense industry policy related research (Liu, 2014), which indicates that system dynamics is suitable for analyzing the overall dynamic and complex issues.

Table 1: System dynamics component symbols

\begin{tabular}{|c|c|c|}
\hline Name & Symbol & Definition and Description \\
\hline Causal & $\mathrm{A} \longrightarrow \mathrm{B}$ & $\begin{array}{l}\text { The arrow between the variables } \\
\text { represents the causal relationship. The } \\
\text { "+" sign represents positive change for } \\
\text { the variables while the "-" sign represents } \\
\text { negative change for the variables. }\end{array}$ \\
\hline $\begin{array}{l}\text { Time } \\
\text { Delay }\end{array}$ & $\mathrm{A} \longrightarrow$ & $\begin{array}{l}\text { Means that after variable A occurs, it will } \\
\text { affect variable B after a time delay }\end{array}$ \\
\hline $\begin{array}{c}\text { Causal } \\
\text { Feedback } \\
\text { Loop }\end{array}$ & $\overbrace{\text { Positive Feedback Loop }}^{(+\infty)(1)}$ & $\begin{array}{l}\text { 1. When a variable in the system affects } \\
\text { other variables and is also affected by } \\
\text { other variables itself, a closed causal } \\
\text { feedback loop is formed. } \\
\text { 2. If the sum for all of the "+" signs or "- } \\
\text { " signs in the loop is an even number, } \\
\text { it is a positive feedback loop and } \\
\text { represents an enhanced loop (often } \\
\text { called the snowball effect). } \\
\text { 3. It is a negative loop when the total } \\
\text { number of "-" in the loop is odd, } \\
\text { which is called a regulation or stable } \\
\text { loop. }\end{array}$ \\
\hline
\end{tabular}




\section{Qualitative Model Construction}

In this study, the researcher used the system dynamics method and systemic thinking to construct a qualitative system dynamic analysis model for the defense industry and project financing in Taiwan, identify key variables and explore the causal relationship between each other via literature review and expert interviews, and develop a qualitative causal feedback loop diagram (Ford and Sterman, 1998). The causal relationship between the variables in the qualitative model and the system structure appropriateness were verified via discussions and inspections with experts and scholars to ensure model validity (Coyle, 1996; 1998; Hsiao, 2014).

\subsection{Military Procurement and Defense Industry Interactive Model}

The acquisition of national defense armament is affected by the external environment as well as internal factors, resulting in different types of acquisition methods. When facing immediate military threats, priority is often given to outsourced weapons in hopes to rapidly increase the military capacity within a short time frame. During the Cold War between the United States and the Soviet Union, many nations decided to join either the United States or the Soviet Union's side in order to obtain advanced armaments because they lacked the military technology to defend against enemy states. For example, mainland China and North Korea received military technology and weapons from the Soviet Union in the 1950s, which posed great threats to Taiwan and South Korea, respectively. Subsequently, Taiwan and South Korea obtained military assistance and weapons from the United States to maintain national security.

The armament acquisition policies for nations worldwide are expected to shift from outsourcing to self-development as permitted by the industrial standards and economic conditions of each nation in order to avoid over-reliance on allies for national defense security, strengthen the core energy of basic industry, and establish the domestic defense industry. Countries such as Israel, India, South Korea, Taiwan, Singapore, Sweden, and Australia have developed towards this trend. However, the breakthrough of crucial components and key technologies still requires the assistance of allies due to the complexity of weapon system technology. So allies often play the role of military technology suppliers. For example, Israel and the U.S. Pratt \& Whitney Company have collaborated to develop the Lavi fighter. U.S. General Dyanmics, Garret Turbine Engine, and other companies have assisted Taiwan in the planning and design of its IDF fighters.

The strategic armament acquisition model for developing countries mostly involves using external procurement to ensure combat readiness since self-development is too slow and may not be cost effective due to the insufficient national technological level and defense industry capabilities. However, subsequent maintenance and supplies may not be available forever. Since the defense industry mostly has an oligopolistic production and small consumption structure, it often requires high profit margins while posing a burden on the defense budget. How to balance external procurement and independent $R \& D$ has become a difficult budget planning 
and defense industry development topic for many countries.

Taiwan has developed its defense industry by combining domestic forces to strive to achieve national defense autonomous. However, due to external constraints such as the scale and economic benefits of the defense industry's market, it has yet to achieve an industrial cluster environment. To avoid the risk of waiting for R\&D, Taiwan uses foreign procurements to obtain armaments as quickly as possible in light of the external threats it faces. In addition to placing a burden on the defense budget, it is often difficult to obtain the most advanced armaments due to the uncertainty of international politics. The subsequent armament maintenance cost is also relatively high when the key technology is controlled by foreign manufacturers (such as the procurement of parts and accessories for the Mirage fighter and the overall logistics support service agreement). This model is not favorable for the defense industry development in Taiwan. Based on national security and overall economic development needs, Taiwan has promulgated special laws to attract and inspire domestic manufacturers to invest in the defense industry supply chain, safely enter the growing defense industry environment, establish a defense armament supply chain and market scale, and give priority to obtain armaments domestically. The goal is to transform national defense into a source of industrial demand, and inspire domestic production projects to drive technological development and industrial upgrading. Take the two important Indigenous Defense Submarine (IDS) and Indigenous Advanced jet trainer (IAJT) policies as an example. They provide incentives for Taiwanese domestic manufacturers to participate in the development, production, and maintenance of defense weapons and equipment; achieve defense industry cultivation in the private sector; increase employment opportunities; improve the economy and enhance national army armament acquisition independence; reduce dependence on foreign sources; and reduce restrictions posed by advanced countries and mainland China in order to achieve the goal of national defense autonomy.

Figure 1 presents a causal loop diagram of interactions between Taiwan's military procurement and the defense industry based on systems thinking. The main goal of national defense armament procurement is to provide strategic responses against hostile threats via external procurements or self-production. Taiwan has a special law providing that the government must give priority to self-produced armaments, and combine private forces to develop the national defense technology industry. After the armaments procurement, the government should release armament R\&D, production, repairs, and other business opportunities to the private sector in order to cultivate the local defense-related industry. Therefore, the higher the demand for military procurement, the more procurement bid contracts the private sector can win. When a private manufacturer wins an armament procurement contract bid, they must raise funds in order to perform the contract and gain revenue. After fulfilling the armament contract delivery, the profits will inspire the manufacturer to increase investment in arms purchases and thereby enhance the scale of the private sector and increase its capabilities to accept more government armament procurement cases (as shown in loop 1). 
Cultivating the domestic defense-related industries can benefit the economy, retain the defense technology in Taiwan, and enhance its defense capabilities. However, self-produced armaments cover complex specificities. Taiwan's private sector lacks $\mathrm{R} \& \mathrm{D}$ investment and cannot connect with international technology. This is a common development bottleneck for the defense industry in Taiwan. Therefore, in addition to armaments procurement, the private sector must continue to invest in technology R\&D. Taiwan must take advantages of the technical support from foreign third-party manufacturers to strengthen the military technical capabilities of private sector and reduce the technological gap. The objective is to enable Taiwan's self-produced armaments to fulfill the arms procurement contracts and meet the national defense strategic goals. The private sector will increase investments due to profits from fulfilling the contracts, which will enhance the scale of the private defense industry and strengthen the defense industry capabilities. The greater the scale of the industry, the more financing the manufacturers can access to undertake and fulfill more military procurement cases and contracts (as shown in Loop 2).

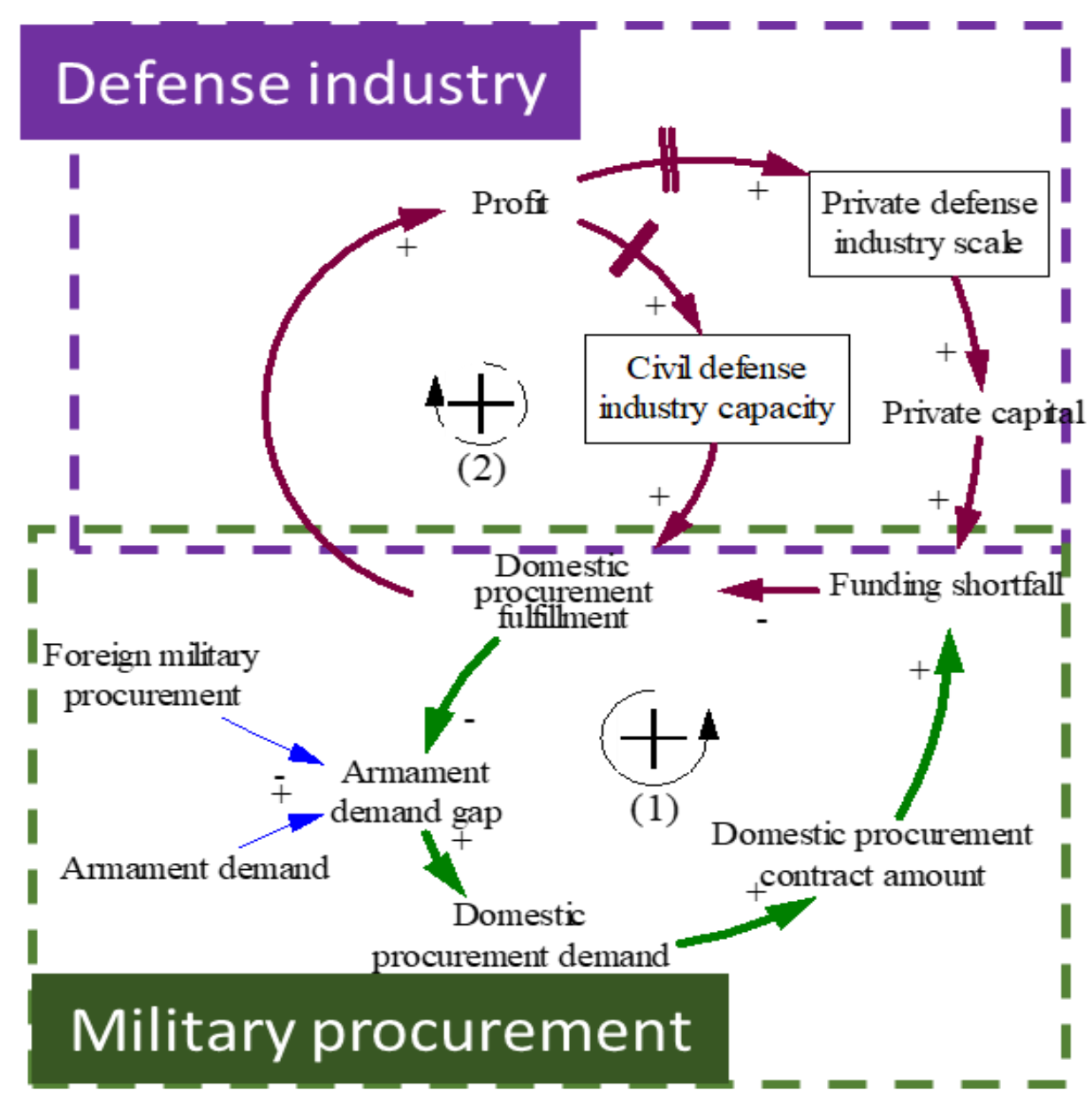

Figure 1: Interactive causal loop diagram for military procurement and defense industry 


\subsection{Project financing causal loop}

Most of the defense industries in advanced countries worldwide are driven by private manufacturer development. When armaments enter the construction phase; early material preparation, equipment procurement, material preparation, and contract payments with suppliers will all increase the initial costs. There are also different financial burdens during different production phases according to the manufacturer's delivery and equipment installation schedule. For manufacturers, the huge cash flow demand is an even tougher challenge compared to the construction. Manufacturers can use the corresponding collaterals as security to obtain bank financing, but they must still face financial turnover risks at different periods. Therefore, manufacturers must have sufficient funds in order to smoothly promote the defense industry. The project financing model allows manufacturers to obtain financing from banks based on the expected profit and feasibility of the investment project. Manufacturers with limited assets can successfully raise capital since this model has essentially eliminated or reduced the guarantee requirements. The OffBalance-Sheet Financing method will not increase the manufacturer's debt, but it allows the manufacturer to reserve room for more loans and gives it the financial flexibility to make other investments.

From a bank's perspective, project financing for the defense industry is risky since the guarantee usually covers only the physical assets or contractual rights of the project. If the project financing fails, the bank would sustain significant loss because the guarantee can only offset a small part of the bad debts. There is also the "information asymmetry" problem between the borrower and the lender, and it is difficult for banks to ensure the borrower's financial plan and repayment ability or determine if the loan will be improperly used by the borrower. The limited recourse feature for project financing also further increases the credit risk for banks.

The foregoing indicates that the defense industry is a high capital intensive industry. The initial investment is huge, the payback period is long, and projects often involve appraisal by specific professionals in the armament fields. There are numerous engineering interfaces, technical services, project management, supplier sources, and system integrated items. The overall contract structure is complex with a high degree of potential credit risk, which in turn discourages financial institutions to undertake project financing. Our nation urgently needs to establish a risk apportion mechanism to reduce credit risks for financial institutions down to an acceptable range. In the future, third-party verification, insurance, credit guarantees, and other risk mitigation or transfer measures may be adopted to guide the financial industry to invest in the defense industry, promote development, and improve the domestic project financing operation system.

Domestic banks in Taiwan have insufficient experience in granting credit to the defense industry. They also have insufficient information and understanding of the technology, engineering, regulations, contracts, finance, and insurance for the defense industry. These shortcomings make it difficult for banks to assess and control the resultant credit and moral integrity risks. For banks to be willing to invest 
in the defense industry project financing, we must effectively reduce the credit risk faced by the banks, and pay particular attention to the negative effects caused by information asymmetry and moral hazards. Therefore, prudent initial risk assessment must be adopted to ensure that the investment project has sufficient repayment capacity, cash flow by the manufacturer is restricted via the financing contract, the capital obtained from the loan are dedicated to project use, and the proceeds from the project are prioritized for loan repayment in order to reduce the project financing credit risk for banks. Specific methods for bank project financing risk reduction are described as follows:

1. It is impossible for banks to fully understand the professional knowledge and related information of each industry when granting credits. Therefore, there must be a certain degree of information asymmetry between the banks and borrowers. Banks can commission professional consultants to perform due diligence investigations for the potential risks and financial status of the target, which are often used during mergers and acquisitions (M\&A). Perform due diligence investigation during project financing to review the technical, engineering, legal, tax, accounting, financial forecasting, insurance, and other aspects of the project. Evaluate all factors that may impact the project operation, and assess the feasibility and solvency of the project. Since due diligence investigations require a wealth of expertise, banks often entrust professional consultants to handle such matters. Use due diligence investigations to assess the risks and feasibility for all aspects of the project, and reduce the information asymmetry problem. Meanwhile, rigorous external monitoring procedures can also be used to prevent failure caused by shortcomings, and thereby avoid high-risk financing cases or the need to require borrowers to improve their operations.

2. In terms of the "financing contract" signed by the bank and borrower, design the project contract structure to reduce or transfer the risk borne by the bank. The key to reducing credit risk is to create a perfect mechanism to control the borrower's cash flow, ensure that the project cash flow is prioritized for operation and repayment, and stipulate certain contract terms to increase the incentives for the borrowers to operate steadily and reduce potential moral risks. For example, the borrower is required to open a designated project account with the host bank to deposit the project funds, and limit the use of the funds to ensure they are fully dedicated to the project. Moreover, set the payment priority order for the project account to ensure that the borrower preferentially uses the proceeds to maintain smooth operations, and repays the project financing principal and interest first instead of prioritizing the funds for other purposes during cash shortfalls and thus damaging the financing bank's rights. 
3. The government should provide financing guarantee and transfer the credit risk from the financing bank group to the government or public institutions. Although the risk cannot be substantially eliminated, the credit risk borne by the banks can be transferred, which can increase the willingness for the banks to provide financing.

Figure 2 presents a causal loop diagram of project financing based on systems thinking. Banks often determine the amount of financing available to manufacturers based on the scale of the manufacturer and the amount of the armament purchase contract. Private manufacturers can also obtain military procurement project financing via bank financing appropriations, and banks can also earn interest income from the loan. The willingness of banks to make loans allows manufacturers to obtain more credit lines. Therefore, as shown in Figure 2, the larger the scale of private manufacturers and the amount of armament procurement contracts, the higher the actual financing amount that the private manufacturers can obtain from bank project financing. This forms the causal feedback relationship of loop (3). Bank interest income will also increase with the increase in project financing from bank loans to private manufacturers, which will strengthen the willingness for banks to make loans and further increase the amount of financing available to private manufacturers. Meanwhile, the banks' risks can be reduced via due diligence investigations, which form the causal feedback relationship in loop (4).

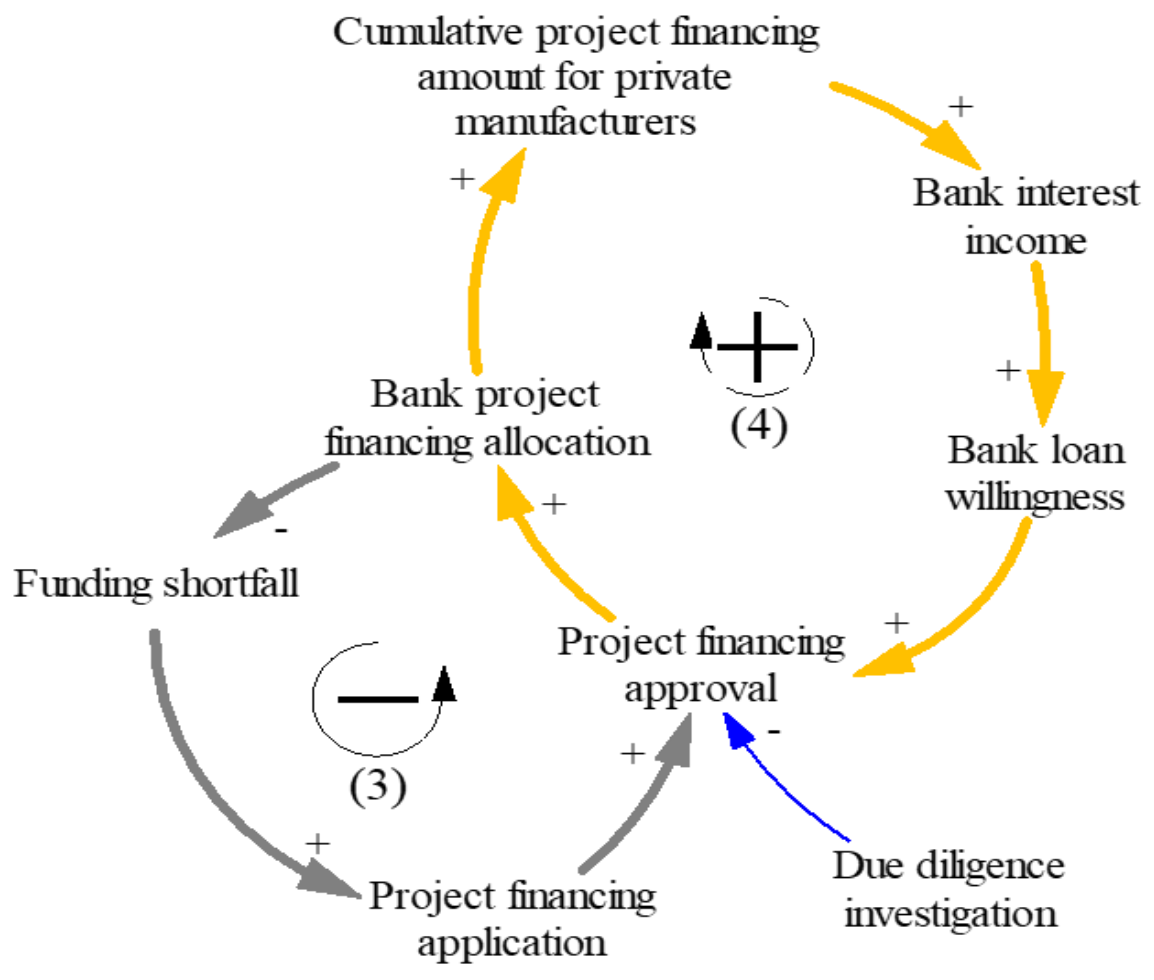

Figure 2: Project financing causal loop diagram 


\subsection{Defense Industry and Project Financing System Dynamics Model}

The defense industry and project financing related issues are affected by the interaction of many mutually causal system environments and variables. It is in essence a complex and dynamic issue. Figure 3 presents a defense industry and project financing system dynamic model that integrates the causal feedback loops in Figures 1 and 2. Among them, four main loops can be used to interpret the system structure. Defense armaments are primarily obtained via foreign or domestic procurement (self-production), and the National Defense Act provides that the government must give priority to self-produced armaments in order to support the domestic defense-related industries. Therefore, the higher the demand for military procurement, the more procurement contracts that private manufacturers can obtain, and said manufacturers must raise funds to fulfill the contract and meet the armament delivery requirements (loop 1). Said manufacturers will increase investment due to profits made from contract performance, and thereby increase the scale of the private defense industry and strengthen the nation's defense industry. The greater the industry scale, the more financing the manufacturers can obtain to undertake more military procurement cases and contract performances (loop 2). In addition to self-owned funds, private manufacturers can obtain bank loans through project financing applications. After a bank approves loans and appropriations to fill the funding gap (loop 3), the bank's willingness to loan is increased due to the loan interest income (loop 4). According to the overall system perspective, the "military procurement," "defense industry," and "project financing" aspects interact with and complement each other. 


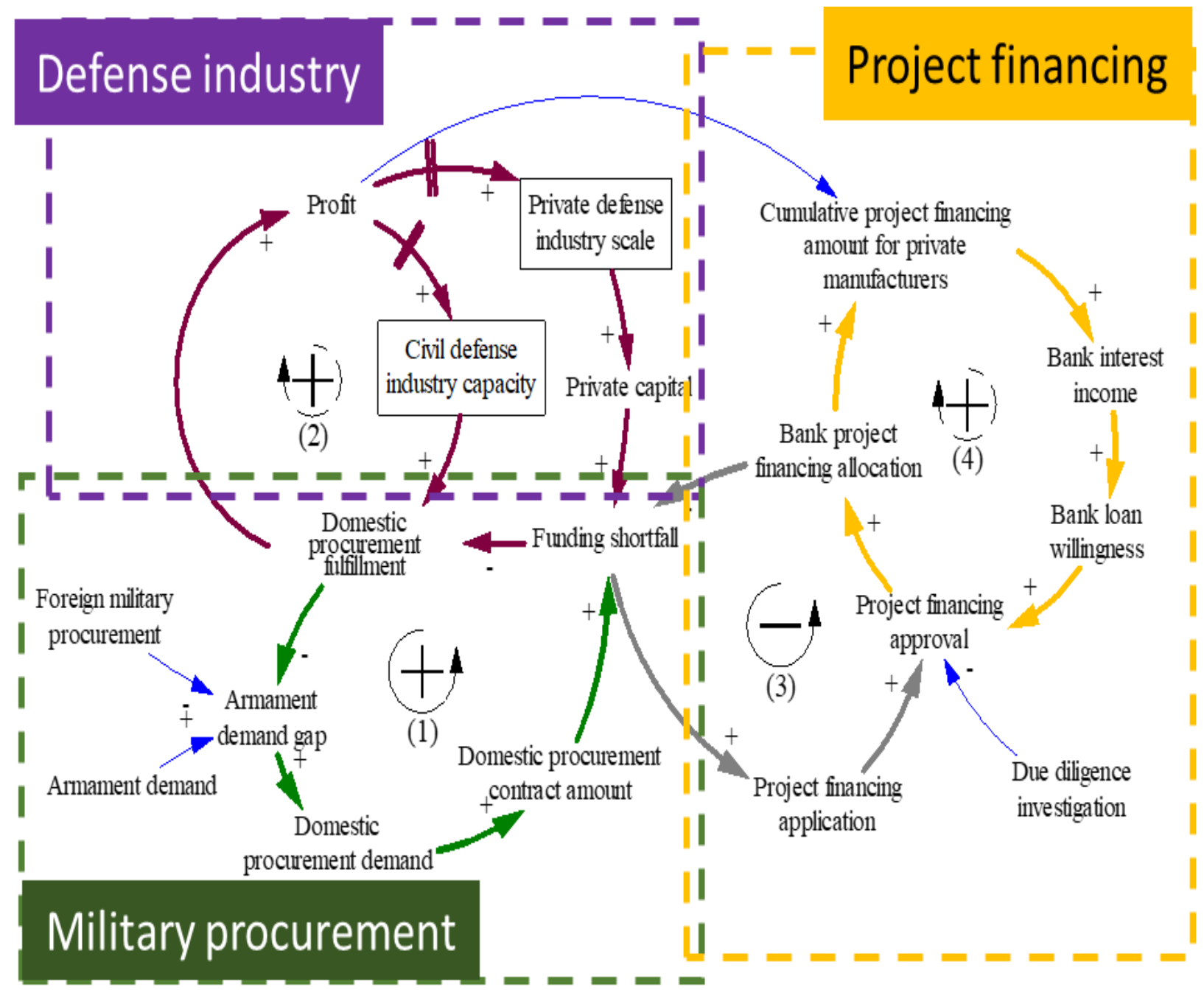

Figure 3: Defense industry and project financing system dynamics model 


\section{Conclusion and Suggestion}

The defense industry is considered to be the most sensitive and cutting-edge technology intensive specialty industry. It often must spend huge amounts on scientific and technological R\&D in order to meet the military needs, and also requires investment from the private sector. National defense autonomously can promote economic development, increase job opportunities in domestic manufacturing, attract foreign investment, and inspire industrial technology upgrading. The economic development can support national defense autonomy, and the domestic manufacturers supply the armaments needed for national defense to improve combat readiness. During the process of integrating national defense autonomy and economic development, the government must transcend itself from merely an armament user in order to integrate national defense and the economy as a whole. Project financing has the advantage of enabling manufacturers with limited assets to raise funds smoothly, which facilitates the policy goal of defense industry development. If rigorous external due diligence investigation procedures can be adopted for project financing; the technical standards, engineering planning, contract structure, and participants of the project can be reviewed in advance to prevent various factors from causing the project to fail while minimizing the "information asymmetry" and "moral hazard" issues to reduce risks. As far as the government is concerned, the government's defense industry policy must strive to encourage private manufacturers to adopt more contractual terms that are beneficial to banks in order to increase their willingness to provide project financing.

National defense development is a complex and dynamic issue. It requires the overall planning and policy promotion of the government as well as the participation of private manufacturers, and must also rely on project financing to inject funds. The relevant factors interact closely with each other. However, the existing literatures mostly focus on the singular issue of national defense industry development policy or large-scale project financing for private projects. There are few studies that focused on the defense industry and project financing simultaneously. The researcher of this study has adopted a holistic perspective to regard the defense industry and project financing as a dynamic system in order to expound on their causal interactions. The goal is to increase our understanding of the defense industry and project financing issues through this holistic study, explore the root causes of the issues, and use the conclusion as a reference for policy-setting. The researcher of this study employed the system dynamics methodology to construct the defense industry and project financing system structure, and qualitatively expounded the complex causal interaction process. Future studies can further consider the resource bias issues for the external procurement and selfproduction of armaments. The model constructed in this study can be expanded and adjusted. Moreover, this model can be further developed into a quantitative system model to perform strategic simulation analysis, which will provide more practical value for decision making. 


\section{References}

[1] Amara, J. (2008). Military industrialization and economic development: Jordan's defense industry. Review of Financial Economics, 17(2), 130-145.

[2] Barroco J., \& Herrera M. (2019). Clearing barriers to project finance for renewable energy in developing countries: A Philippines case study. Energy Policy, 135, 111008

[3] Beal, T. (2001). SMEs and Government Policies on ICT. Society for Global Business and Economic Development, Symposium held at Crowne Plaza JFK Airport, New York.

[4] Beck, T., \& Demirguc-Kunt, A. (2006). Small and medium-size enterprises: Access to finance as a growth constraint. Journal of Banking \& finance, 30(11), 2931-2943.

[5] Benoit, E. (1978). Growth \& Defense in Developing Countries. Economic Development \& Cultural Change, 26(2), 271-280.

[6] Blom, M., Castellacci, F., \& Fevolden, A. M. (2013). The trade-off between innovation and defense industrial policy A simulation model analysis of the Norwegian defense industry. Technological forecasting and social change, 80(8), 1579-1592.

[7] Bougrain, F., \& Haudeville, B. (2002). Innovation, collaboration and SMEs internal research capacities. Research policy, 31(5), 735-747.

[8] Broome, L. L. (2002). Framing the Inquiry: The Social Impact of Project Finance--A Comment on Bjerre. Duke J. Comp. \& Int'l L.

[9] Chen, J. H., \& Jan, T. S. (2005). A System Dynamics Model of the Semiconductor Industry Development in Taiwan. Journal of the Operational Research Society, 56(10), 1141-1150.

[10] Chen, J. H., \& Jan, T. S. (2005). A Variety-increasing View of the Development of the Semiconductor Industry in Taiwan. Technological Forecasting and Social Change, 72(7), 850-865.

[11] Clews, R. J. (2016). Project Finance for the International Petroleum Industry. New York: Academic Press.

[12] Corielli, F., Gatti, S., \& Steffanoni, A. (2010). Risk shifting through nonfinancial contracts: Effects on loan spreads and capital structure of project finance deals. Journal of Money, Credit and Banking, 42(7), 1295-1320.

[13] Cory, K., Coughlin, J., Jenkin, T., Pater, J., \& Swezey, B. (2008). Innovations in wind and solar PV financing. Colorado: National Renewable Energy Laboratory. (NREL No. TP-670-42919)

[14] Coyle, G. (1998). The Practice of System Dynamics: Milestones, Lessons and Ideas from 30 years. System Dynamic Review, 14(4), 343-365.

[15] Coyle, G. (1996). System Dynamics Modelling-A practical approach. London, UK: Chapman \& Hall.

[16] Craig, V., \& AirPlan-Malaysia, H. (1999). Risk and Due Diligence in Airport Privatisation. Airport Privatisation. 
[17] Cruz, C. O., \& Sarmento, J. M. (2018). The price of project finance loans for highways. Research in Transportation Economics, 70, 161-172.

[18] Daube, D., Vollrath, S., \& Alfen, H. W. (2008). A comparison of Project Finance and the Forfeiting Model as financing forms for PPP projects in Germany. International Journal of Project Management, 26(4), 376-387.

[19] Esty, B. C. (2004). Why study large projects? An introduction to research on project finance. European Financial Management, 10(2), 213-224.

[20] Finnerty, J. D. (2013). Project Financing: Asset-Based Financial Engineering. John Wiley \& Sons.

[21] Ford, D. N., \& Sterman, J. D. (1998). Expert knowledge elicitation to improve formal and mental models. System Dynamics Review, 14(4), 309-340.

[22] Gatti, S. (2018). Introduction to the Theory and Practice of Project Finance. In Gatti, S. (3rd ed.), Project Finance in Theory and Practice: Designing, Structuring, and Financing Private and Public Projects. New York: Academic Press.

[23] Gatti, S. (2013). Project Finance in Theory and Practice: Designing, Structuring, and Financing Private and Public Projects. Academic Press.

[24] Head, R. C. (1974). Comparative Defense Policy. Bahimore and London: The Johns Hopkins University Press.

[25] Hsiao, C. T. (2014). Industrial Development Research by Systems Approach in NICs: The Case in Taiwan. Systems Research and Behavioral Science, 31(2), 258-267.

[26] Hsiao, C. T., \& Liu, C. S. (2012). Dynamic Modeling of the Development of the DRAM Industry in Taiwan. Asian Journal of Technology Innovation, 20(2), 277-293.

[27] Hsiao, C. T., Chang, P. L., Chen, C. W., \& Huang, H. H. (2011). A Systems View for the High-Tech Industry Development: A Case Study of Large-Area TFT-LCD Industry in Taiwan. Asian Journal of Technology Innovation, 19(1), 117-132.

[28] James, G. M. (1978). Living Systems. Mcgraw-Hill Book Company.

[29] Jan, C. G. (2005). Defense Technology in Society: Lessons from Large Arms Importers. Technology in Society, 27, 181-197.

[30] Jan, T. S., \& Jan, C. G. (2000). Development of weapon systems in developing countries a case study of long range strategies in Taiwan. Journal of the Operational Research society, 51(9), 1041-1050.

[31] Jan, T. S., \& Hsiao, C. T. (2004). A Four-role Model of the Automotive Industry Development in Developing Countries: a Case in Taiwan. Journal of the Operational Research Society, 55(11), 1145-1155.

[32] John, D. Finnerty. (1996). Project Financing: Asset-Based Financial Engineering.

[33] John, T. A., \& John, K. (1991). Optimality of project financing: Theory and empirical implications in finance and accounting. Review of Quantitative Finance and Accounting, 1(1), 51-74. 
[34] Kaivanto, K., \& Stoneman, P. (2007). Public provision of sales contingent claims backed finance to SMEs: A policy alternative. Research Policy, 36(5), 637-651.

[35] Kakimoto, R., \& Senneviratne, P. N. (2000). Financial risk of port infrastructure development. Journal of Waterway, Port, Costal, and Ocean Engineering, 126(6), 281-287.

[36] Kann, S. (2009). Overcoming barriers to wind project finance in Australia. Energy Policy, 37(8), 3139-3148.

[37] Katharine C. (2004). Baragona, Symposium: Markets in Transition: Reconstruction and Development: Part Two - Building Up to a Drawdown: International Project Finance and Privatization - Expert Presentations on Lessons to be Learned: Project Finance, 18 Transnat'1 Law. 139.

[38] Keeley, A. R., \& Matsumoto, K. I. (2018). Investors' perspective on determinants of foreign direct investment in wind and solar energy in developing economies-Review and expert opinions. Journal of cleaner production, 179, 132-142.

[39] Landau, D. (1992). The Impact of Military Spending on Economic Growth in LDCs. Washington, DC: Mimeo.

[40] Leigland, J., \& Russell, H. (2009). Another lost decade? Effects of the financial crisis on project finance for infrastructure. Gridlines. The World Bank Group-Public-Private Infrastructure Advisory Facility, 48.

[41] Liu, P. L. (2014). The Development of a Military Aircraft Industry for Latecomers: The Case of Taiwan. The Korean Journal of Defense Analysis, 26(1), 97-115.

[42] Meadows, D. H., Meadow, D. L., Randers, J., \& Behrens, W. W. (1972). The Limits to Growth: a Report of the Club of Rome's Project on the Predicament of Mankind. New York: Chelsea Green Publishing Company.

[43] Meadows, D. H., Randers, J., \& Meadow, D. L. (2004). Limits to Growth: The 30-Year Update. New York: Chelsea Green Publishing Company.

[44] Merna, T., \& Njiru, C. (2002). Financing infrastructure projects. London: Thomas telford.

[45] Mihaela, B. G. R. (2014). Statistical methods applied to the financial analysis of a publicly funded investment project. Procedia Economics and Finance, 10, 304-313.

[46] Mohamed, S., \& McCowan, A. K. (2001). Modeling Project Investment Decisions under Uncertainty Using Possibility Theory. International Journal of Project Management, 19(4), 231-241.

[47] Myers, S. C., \& Majluf, N. S. (1984). Corporate financing and investment decisions when firms have information that investors do not have. Journal of financial economics, 13(2), 187-221.

[48] Navarro, P. (2019). President Trump's Conventional Arms Transfer policy is strengthening America and its allies. Retrieved September 24, 2019.

[49] Purpura, P. (2007). Terrorism and Homeland Security: An Introduction with Applications. MA: Elsevier. 
[50] Sainati, T., Locatelli, G., \& Smith, N. (2019). Project financing in nuclear new build, why not? The legal and regulatory barriers. Energy policy, 129, 111-119.

[51] Senge, P. (1990). The Fifth Dimension: The Art and Practice of the Learning Organization. New York: Doubleday.

[52] Shen, L. Y., \& Wu, Y. Z. (2005). Risk Concession Model for Built/Operate/Transfer Contract Projects. Journal of Construction Engineering and Management, 131(2), 211-220.

[53] Spedding, L. S. (2009). Due diligence handbook: Corporate governance, risk management and business planning. MA: Elsevier.

[54] Sterman, J. D. (1988). Modeling the Formation of Expectations: The History of Energy Demand Forecasts. International Journal of Forecasting, 4(2), 243259.

[55] Sterman, J. (2000). Business Dynamics: Systems Thinking and Modeling for a Complex World. Irwin: McGraw-Hill.

[56] Trappey, A. J. C., Trappey, C. V., Hsiao, C.T., Ou, J-R., Li, S-J., \& Chen, K. W. P. (2012). An Evaluation Model for Low Carbon Island Policy: The Case of Taiwan's Green Transportation Policy. Energy Policy, 45, 510-515.

[57] Wang, C. N., Nguyen, X. T., Le, T. D., \& Hsueh, M. H. (2018). A partner selection approach for strategic alliance in the global aerospace and defense industry. Journal of Air Transport Management, 69, 190-204.

[58] Yates, C., \& Leybourne, M. (2019). Financing offshore wind in taiwan. Journal of National Development Studies, 18(2), 125-152.

[59] Yeo, K. T., \& Tiong, R. L. (2000). Positive management of differences for risk reduction in BOT projects. International Journal of Project Management, 18(4), 257-265. 